\begin{tabular}{c} 
Volume and Issues Obtainable at Center for Sustainability Research and Consultancy \\
Journal of Business and Social Review in Emerging Economies \\
ISSN: 2519-089X (E): 2519-0326 \\
Volume 6: Issue 3 September 2020 \\
CSRட \\
Journal homepage: $\underline{\text { www.publishing.globalcsrc.org/jbsee }}$ \\
\hline
\end{tabular}

\title{
Bank-Specific Attributes and Operational Efficiency: Evidence from Efficient-Structure Hypothesis
}

\author{
${ }^{1}$ Onipe Adabenege Yahaya, ${ }^{2}$ Benjamin Iorsue Awen \\ ${ }^{1}$ Department of Accounting, Nigerian Defence Academy, Kaduna, Nigeria, yoadabenege@nda.edu.ng \\ ${ }^{2}$ Department of Business Education, Federal College of Education, Zaria, Nigeria, awenbenjamin60@gmail.com
}

\section{ARTICLE DETAILS \\ History \\ Revised format: August 2020 \\ Available Online: September \\ 2020}

\section{Keywords}

audit quality, board gender, capital expenditure ratio,

intellectual capital, leverage, profitability.

JEL Classification

C33, D22, G21, H21, M41

\begin{abstract}
Purpose: Corporate stakeholders are concerned about the operational efficiency of banks for obvious reasons. Banks play important intermediation role between the deficit and surplus sectors of the economy. Yet, there are limited empirical studies in Nigeria that examine the effects of bank attributes on their operational efficiency. This paper is an attempt to bridge this empirical gap.

Design/Methodology/Approach: Data was extracted from the website of the Nigerian Stock Exchange. The dependent variable is operational efficiency and the independent variables are bank-specific attributes.

Findings: The regression models indicate that asset turnover is superior to operating expenses to sales ratio. The results further indicate that only profitability, leverage, intellectual capital and capital expenditure ratio show significant effects.

Implications/Originality/Value: In view of these results, we suggest that bank managers should pay greater attention to profit, total assets, debt structure, intellectual capital, cash from operations and capital expenditures. This is one of the few empirical studies that examine the impact of bankspecific traits on bank operational efficiency in Nigeria. The paper considers that the influences of bank-specific features on their operational efficiency are worth studying.
\end{abstract}

(C) 2020 Center for Sustainability Research and Consultancy Pakistan under a Creative Commons Attribution-NonCommercial-ShareAlike 4.0

Corresponding author's email address: yoadabenege@ nda.edu.ng

Recommended citation: Yahaya, O. A., \& Awen, B. I. (2020). Bank-specific attributes and operational efficiency:

Evidence from efficient-structure hypothesis. Journal of Business and Social Review in Emerging Economies, 6(3), 1087-1098.

\section{Introduction}

Banks are very critical part of the financial system because they provide bridge between deficit and surplus sectors by way of credit facilities and safe custody of cash and marketable securities, among several other roles played by banks. They are probably the single most robust sector upon which other sectors of the economy rely heavily. Thus, banks must be effective and efficient to be able to deliver on these expectations and this is regardless of whether the environment in consideration is a developed economy or an emerging economy. While effectiveness addresses the bottom-line, that is, results, efficiency addresses the quality of results, in terms of how much inputs are expended to achieve the outputs. Therefore, efficiency is a function of the relationship between outputs and inputs and this association is particularly more of interest given the current global financial and economic crises. This requires every 
creative and innovative ideas, minds and strategies to fix and save the world from extreme poverty, unemployment, under-employment, hunger, desolation, hopelessness and emptiness.

In this study, efficiency is seen from two broad perspectives; how bank assets are turned over, that is, the manner and quality in which the assets of a bank are put into generating revenue (income), otherwise also known as assets turnover and how much of this revenue is used up to cover operations, otherwise, often referred to as operating expenses. Asset turnover is a financial ratio that measures the efficiency of a bank's use of its assets in generating revenue or income. Higher values are desirable particularly in the long run, otherwise, it could spell failure for the bank. In the same view, operating expenses to sales ratio is a financial ratio which measures the efficiency of the bank by comparing and contrasting total operating expenses with net sales. A higher ratio is evidence of management poor competence and ability in use of resources to generate wealth.

It is useful to note at this juncture that operational efficiency of a bank is only a dream without consideration for bank internal factors that have capacity to vary it. These factors are very often referred to as bank attributes, characteristics, traits or features. They are many including but not limited to age, asset tangibility, audit quality, board gender, board size, capital expenditure quality, credit risk, dividend payout, effective income tax rate, growth, intellectual capital, leverage, liquidity, profitability and size. However, for the purpose of this study, 11 out of these 15 bank-specific attributes were included in the model after testing for factor loadings, rotations and predictive values and evidence shows that they met the minimum requirements to enter into the econometric models as suggested by Kaiser (1960, 1970) to retain those factors with eigenvalues equal or higher than 1.

Audit quality simply suggests that the audit meets or fail to meet the legal and professional requirements. It means commitment to make sound judgments and ensuring that the right steps are taken in the course of the audit. Board gender is a term often used to connote the presence of women on the board of directors. It refers to the proportion of women board members relative to the total board members. The size of the board is the number of directors on the board, whether they are executive or non-executive directors. Non-executive directors are also called independent directors.

Dividend payout is the amount of income paid out to shareholders out of the net income of the bank. It is one of the benefits of investing in a firm; the other benefit is capital gain (appreciation). Profitability is a financial state, in which the bank is able to generate revenue than the expenses it incurs. While this state is highly desirable, it is difficult in the short-term, essentially due to forming, norming and storming factors that new firms are faced with at formative stage in their life cycle (Yahaya \& Onyabe, 2020).

Corporate tax is a major source of revenue to governments in Nigeria. The ongoing global economic and financial crises have made company income tax more veritable. It has been become a major source of interests for firms and governments. Although, the tax rate is fixed for companies, the effective tax rate varies from company to another. Capital expenditure ratio is a measure of how much of a firm's cash is devoted to capital expenditure, which actually is the strength of future cash flows arising from investments in acquiring new assets and upgrading existing assets. Intellectual capital is the unseen asset of a firm including its human, structural, relational capital and capital employed. Intellectual capital has made a considerable difference between most valued companies and those behind in the packs.

The size of a firm is a measure of economic and financial power and competitive advantage. Before bank consolidation leading to the end of 2005, finance literature in Nigeria was full of words 'big banks' and 'small banks'. However, after the mandatory capital raise, all deposit money banks were described as mega banks. Size is often seen from several perspectives, evidenced by total assets, sales, equity, number of employees and number of subsidiaries or branches. Similarly, age is another very important factor because it often confers advantages of experience, motivated employees, industry market share and strategic locations; however, this may not be true in all cases. Scholars believe that age is an advantage where complacency is not allowed to set in. Leverage, also known as gearing, or debt provides opportunity for corporations to borrow amidst high cost of equity capital since cost of debt is low compared with cost of equity or preference share; thus, enables corporations to achieve an optimum capital structure. 
This paper is significant in terms of contributions to policy improvement for the government and its regulators. Also, it provides performance improvement lessons for the management of the listed deposit money banks. For future research, this paper provides empirical evidence that researchers can tap from. It will also improve the state of body of knowledge, conceptually and theoretically. Regulators such the Central Bank of Nigeria (CBN) and Securities and Exchange Commission (SEC), board of directors and management are guided by the outcome of the study. Other stakeholders such the Federal Inland Revenue Service (FIRS), customers, employees, and the generality of the public stand to gain from the results of the study. In addition, deposit money banks will benefit from the study because they will be able to clearly identify factors that have greater influence than others. Furthermore, the scope of the study covers a period of 13 years (2007-2019) and is restricted to deposit money banks that are listed on the floor of the Nigerian Stock Exchange and remain quoted throughout the period of coverage. The remaining part of the paper is devoted to literature review and hypotheses development, methodology, empirical results and discussion and conclusion and recommendations.

\section{Literature Review and Hypotheses Development}

The efficient-structure hypothesis is used in this study by examining the influence of firm-specific attributes on bank efficiency. This theory was used by Homma et al. (2012) to explain the association between firm growth and efficiency in the banking industry. However, Bhatti and Hussain (2010) examined the evidence on efficient-structure theory using 20 commercial banks in Pakistan over a period of 9 years (1996-2004) and failed to find any evidence in support of the theory.

The quality of audit has been found to be associated with operational efficiency. For example, Boubaker et al. (2018) assess the effect of audit quality on firm efficiency for 125 French-listed companies over 2008-2015. The results show that efficiency increases with audit quality. However, some other scholars failed no find any evidence of significance. For example, Ugwu et al. (2020) examined the impact of audit quality on efficiency of 15 listed deposit money banks in Nigeria covering 2011-2017 and found negative and insignificant relationship between audit quality, measured by audit fee and efficiency. In view of these glaring conflicting findings, this paper predicts that:

\section{$H_{1}$ : Audit quality has no significant effect on operational efficiency.}

Board gender was found to have significant impact on operational efficiency. For example, Jeroh et al. (2015) examined the influence of corporate governance and financial performance on audit quality of 58 listed firms in Nigeria over a period of 24 years (1990-2013) and found that board gender influences audit quality. Similarly, Adeabah et al. (2019) examined the influence of board gender and corporate governance on bank efficiency in Ghana using 21 banks for the period (2009-2017) and found a that board gender has a positive effect on bank efficiency. However, Zulkufly et al. (2015) examined the influence of gender diversity, board monitoring on bank efficiency using a panel of ASEAN-5 listed commercial banks over the period (1999-2012) and found that gender diversity in bank board decreases efficiency. Given these contrasting views, this paper proposes that:

\section{$\mathrm{H}_{2}$ : Board gender has no significant impact on operational efficiency.}

Board size has been found to have significant effect on operational efficiency. For instance, Tanna et al. (2011) examined the influence of board size and composition on bank efficiency using a sample of 18 banks in the UK between 2001 and 2006 and found positive association between board size and efficiency. Also, Jeroh et al. (2015) found that board size positively influences audit quality. Similarly, Zulkufly et al. (2015) also found that board size increases bank efficiency. Adeabah et al. (2019) also found board size to have a positive effect on bank efficiency. Meanwhile, Agoraki et al. (2010) interrogated a panel of large European banks during the period (2002-2006) and found that board size has a negative influence on bank efficiency. In view of these glaring conflicting findings, this paper predicts that:

\section{$H_{3}$ : Board size has no significant influence on operational efficiency.}


Dividend paid to shareholders has been found to have significant impact on operational efficiency. For example, Enekwe et al. (2015) examined the effect of dividend payout on efficiency of quoted cement firms in Nigeria over a period 12 years (2003-2014) and found that dividend payout has positive and significant effect on efficiency. However, other scholars failed to find any evidence of significance. For example, Ahmad and Muqaddas (2016) examined the influence of dividend policy using dividend payout ratio on efficiency using panel data of 10 commercial banks listed at the Pakistan Stock Exchange (PSX) for a period of 9 years (2006-2014) and found negative association between dividend payout and efficiency. In view of these different positions, this paper suggests that:

\section{$H_{4}$ : Dividend payout does not have significant effect on operational efficiency.}

Profitability is a desirable state for every business because the continued absence of it can spell failure. Some empirical studies found profitability to have significant influence on operational efficiency. For example, Werner and Moormann (2009) examined the effect of profitability on efficiency of 5 large economies within the European Union over the period (1998-2005) and found that profitable banks operate with higher efficiency than their competitors. Chan and Abd-Karim (2010) examined the effects of profitability on efficiency of commercial banks in developing countries and the results indicate that profitability measured by return on assets has positive effect on bank efficiency. Also, Jeroh et al. (2015) found that profitability influences efficiency. Setiawan and Kodralillah (2017) examined the effect of profitability (return on assets) on efficiency of Islamic commercial banks in Indonesia between 2012-2016 using fixed effects model and found profitability to have significant effect on bank efficiency. Also, Lotto (2019) found bank profitability to have both significant and positive impact on operating efficiency. However, some other works failed to find any evidence of significance. For example, Lotto (2019) failed to find any significant effect between profitability and bank efficiency. In view of these conflicting findings, this paper predicts that:

\section{H5: Profitability does not have significant influence on operational efficiency.}

Gaganis et al. (2013) explore the empirical association between effective tax rate and bank efficiency using a sample of 533 listed deposit money banks in 46 countries over the period (2001-2009). Results show that tax rate increases efficiency, however, non-linearly, which means that after a certain period, any increase in tax will adversely affect bank efficiency. Gawehn (2019) examines empirical literature linking corporate income tax with bank efficiency and concludes that taxes distort bank efficiency. In these two conflicting results, this paper predicts that:

\section{H6: Effective tax rate does not significantly influence operational efficiency.}

Bitar et al. (2018) examine the influence of capital expenditure ratio on bank efficiency using a sample of 1,992 banks operating in 39 Organization for Economic Cooperation and Development countries and demonstrate that capital expenditure ratios improve bank efficiency. Chan and Abdkareem (2010) also explore the influence of capital expenditure ratio on bank efficiency of deposit money banks in developing countries and found negative effect on bank efficiency. In view of these positions, the paper suggests that:

\section{H7: Capital expenditure ratio does not have significant influence on operational efficiency.}

Buallay et al. (2020) examine the effect of intellectual capital on bank efficiency of 59 banks over a period of 5 years and found positive association between the two variables. Onyekwelu et al. (2017) assess the impact of intellectual capital on efficiency in the banking industry in Nigeria and found positive and significant impact on bank efficiency. Also, Ewereoke (2018) explores the impact of intellectual capital on efficiency using firm processes and reports significant effect. Ekwe (2013) examines the impact of intellectual capital on bank efficiency (revenue growth) and found significant positive relationship between them. The null hypothesis suggests that:

\section{H8: Intellectual capital has no significant impact on operational efficiency.}

Page Jr. (1984) investigated the association between technical efficiency and firm size in 4 Indian manufacturing sectors. Firm size was found to have positive association with efficiency. Similarly, Lundvall and Battese (2000) examine the association among firm size, age and efficiency using 235 manufacturing firms in Kenya. The evidence 
supports the argument that firm size has a positive and significant effect. In addition, Homma et al. (2012) examined the impact of firm growth on efficiency in the banking industry and found that more efficient banks become larger. Sulub (2014) assessed whether bank size, age and leverage are important factors to determine its profitability? The result shows that size has significant positive impact on bank efficiency. Furthermore, Eriki and Osifo (2015) examined the determinants of bank performance efficiency using 19 banks in 2009 and found that size is positively associated with bank performance efficiency. In view of these empirical evidences, the paper predicts the null hypothesis that:

\section{H9: Firm size does not have significant influence on operational efficiency of banks.}

Firm age has been found to be associated with bank efficiency. Some scholars argue that older banks have gained economy of scope and scale, learning curve, return on learning and lower cost structure based on years of operations. While Sulub (2014) found age to have negative effect on bank efficiency; Eriki and Osifo (2015) found age to be positively associated with bank performance efficiency. Lundvall and Battese (2000) found age to have insignificant effect on efficiency. Given these contrasting results, the study predicts that:

\section{H10: Age does not have significant influence on bank operational efficiency.}

Leverage (gearing) provides banks with cheap source of capital, without having to put pressure on equity holders for recapitalization. This helps to bring down the weighted average cost of capital and by extension ensure bank cost and profit efficiency. Leverage has been found to be related to bank efficiency. Gadzo and Asiamah (2018) interrogated the association between leverage and performance of unlisted banks in Ghana. Results indicated that leverage has positive correlation with bank efficiency measured by rate of profit. However, Sulub (2014) found leverage to have insignificant impact on bank efficiency. In view of these contradictions, the paper proposes that:

$H_{11}$ : Leverage does not have significant influence on operational efficiency.

\section{Research Design and Methodology}

This study is empirical in nature. The population is 14 and sample is 12, having removed Diamond Bank and Skye Bank, both which have been taken over by Access Bank and Polaris Bank, respectively. Data was extracted from the annual reports and accounts of the banks from the website of the Nigerian Stock Exchange (www.nse.com.ng). The outcome variable is operating efficiency, measured by the ratio of operating expenses to sales (OPES) and asset turnover (ASST). Firm attributes used after carrying out exploratory factor analysis are profitability, audit quality, dividend payout, board size, board gender, leverage, effective tax rate, intellectual capital, listing age, firm size, and capital expenditure ratio. The data was analyzed with descriptive statistics (number of observations, mean, standard deviation, minimum mean, and maximum mean) and influential statistics (correlation matrix, regression analysis). Diagnostic checks and post estimation tests (normality of residuals, homoscedasticity, multicollinearity, panel effects and Granger non-causality) were carried out. Two models were adapted and tested based on the initial model used by Lotto (2019):

OPES $_{i, t}=\alpha+\beta_{1}$ ROTA $_{i, t}+\beta_{2}$ AUDQ $_{i, t}+\beta_{3}$ DPOT $_{i, t}+\beta_{4}$ BSIZ $_{i, t}+\beta_{5}$ BGDR $_{i, t}+\beta_{6}$ TDTA $_{i, t}$

$+\beta_{7} \mathrm{EITR}_{\mathrm{i}, \mathrm{t}}+\beta_{8} \mathrm{INTC}_{\mathrm{i}, \mathrm{t}}+\beta_{9} \mathrm{LAGE}_{\mathrm{i}, \mathrm{t}}+\beta_{10} \mathrm{FSIZ}_{\mathrm{i}, \mathrm{t}}+\beta_{11} \mathrm{CAPE}_{\mathrm{i}, \mathrm{t}}+\varepsilon_{i, \mathrm{t}}$

$\mathrm{ASST}_{\mathrm{i}, \mathrm{t}}=\alpha+\beta_{1} \mathrm{ROTA}_{\mathrm{i}, \mathrm{t}}+\beta_{2} \mathrm{AUDQ}_{\mathrm{i}, \mathrm{t}}+\beta_{3} \mathrm{DPOT}_{\mathrm{i}, \mathrm{t}}+\beta_{4} \mathrm{BSIZ}_{\mathrm{i}, \mathrm{t}}+\beta_{5} \mathrm{BGDR}_{\mathrm{i}, \mathrm{t}}+\beta_{6} \mathrm{TDTA}_{\mathrm{i}, \mathrm{t}}$

$+\beta_{7}$ EITR $_{i, t}+\beta_{8}$ INTC $_{i, t}+\beta_{9}$ LAGE $_{i, t}+\beta_{10}$ FSIZ $_{i, t}+\beta_{11}$ CAPE $_{i, t}+\varepsilon_{i, t}$.

Whereas:

OPES = Operating expenses to sales ratio, measured by total operating expenses divided by net sales (Chan \& Karim, 2010).

ASST = Asset turnover, measured by sales divided by total assets (Chan \& Karim, 2010; Yahaya \& Onyabe, 2020). ROTA = Return on total asset, measured by (Chan \& Karim, 2010; Onwe et al., 2020; Yahaya, 2018; Yahaya, 2019; Yahaya et al., 2019; Yahaya \& Onyabe, 2020). 
AUDQ = Audit quality, measured by the Big 4 (Abu et al., 2018; Abu et al., 2019; Salawu et al., 2017a; Salawu et al., 2017b).

DPOT $=$ Dividend payout measured by (Yahaya, 2017).

BSIZ = Board size, measured by the directors on the board (Yahaya \& Bilyaminu, 2020).

BGDR = Board gender, measured by the proportion of female directors to the board members (Yahaya \& Bilyaminu, 2020).

TDTA $=$ Total debt to total assets, measured by total debt divided by total assets (Gadzo \& Asiamah, 2018; Sulub, 2014).

EITR = Effective income tax rate, measured by the tax paid divided by net profit (Gaganis et al., 2013; Gawehn, 2019).

INTC = Intellectual capital, measured by valued added intellectual capital score (Buallay, 2020; Ewereoke, 2018; Onyekwelu et al., 2017).

LAGE = Listing age, measured based on the formula (current year less year of listing) as used by Shumway (2001) and Yahaya et al. (2017).

FSIZ = Firm size, measured as natural log of total assets (Eriki \& Osifo, 2015; Sulub, 2014).

CAPE $=$ Capital expenditure ratio measured by capital expenditure divided by cash (Bitar, 2018; Chan \& Abdkareem, 2010).

$\mathrm{i}=$ Firm script (in this case, $\mathrm{i}=12$ firms)

$\mathrm{t}=$ Time script (in this case, $\mathrm{t}=13$ years)

$\alpha=$ Constant

$\beta_{1-11}=$ Coefficients measuring slope

$\varepsilon=$ Idiosyncratic error term

\section{Empirical Results and Discussion}

This section presents results and discusses findings in the context of previous empirical studies, a priori expectations and the efficient-structure theory.

Table 1

Factor Analysis Scoring Coefficients

\begin{tabular}{lllllll}
\hline Factors/Variables & 1 & 2 & 3 & 4 & 5 & 6 \\
\hline ROTA & -.053 &. $\mathbf{4 8 7} \sqrt{ }$ & .036 & .073 & -.133 & .083 \\
LIQT & .027 & .056 & -.503 & .015 & -.013 & -.281 \\
AUDQ & .033 & .201 & -.301 & .083 & -.110 &. $\mathbf{2 5 8} \sqrt{ }$ \\
DPOT & .022 & .178 &. $\mathbf{5 3 3} \sqrt{ }$ & .071 & -.060 & .019 \\
BSIZ &. $\mathbf{3 1 5} \sqrt{ }$ & -.120 & .189 & -.147 & -.080 & -.152 \\
BGDR & -.017 & .222 & .164 &. $\mathbf{4 4 3} \sqrt{ }$ & .068 & -.113 \\
TDTA & -.217 & -.184 & -.011 & .206 & $.259 \sqrt{ }$ & -.023 \\
EITR & -.009 & .024 & .119 & -.054 & .049 &. $\mathbf{8 0 1} \sqrt{ }$ \\
INTC & -.038 & .312 & .057 & .016 &. $\mathbf{3 7 7} \sqrt{ }$ & -.016 \\
LDER & .220 & -.116 & -.045 & .030 & -.181 & .034 \\
LAGE &. $\mathbf{3 0 9} \sqrt{ }$ & -.353 & -.059 & .209 & -.082 & .248 \\
SIZE &. $\mathbf{3 2 1} \sqrt{ }$ & -.033 & .052 & .080 & .161 & -.010 \\
GROW & .067 & -.032 & .039 & -.628 & .155 & .042 \\
CAPE & .028 & -.139 & -.021 & -.148 & $\mathbf{. 6 7 2} \sqrt{ }$ & .055 \\
ASTG & -.328 & -.002 & .128 & .115 & -.058 & .021 \\
\hline
\end{tabular}

A closer look at Table 1 indicates the predictive power of the variables given the 6 factors that have eigenvalues greater than 1.0 and therefore selected for the study. Effective income tax rate (factor 6) has the higher 80.1\%; followed by capital expenditure ratio (factor 5) $67.23 \%$, dividend payout (factor 3) 53.3\%, profitability (factor 2) $48.67 \%$, board gender (factor 4) 44.27\%, intellectual capital (factor 5) 37.67\%, firm size (factor 1) 32.12\%, board size (factor 1) $31.52 \%$, firm age (factor 1) $30.92 \%$, leverage (factor 5) $25.98 \%$ and audit quality (factor 6) $25.86 \%$. 
Table 2

Results of Descriptive Analysis

\begin{tabular}{llllll}
\hline Variable & Obs & Mean & Std. Dev. & Min & Max \\
\hline ROTA & 153 & 1.374 & 2.940 & -20.23 & 9.54 \\
AUDQ & 153 & .797 & .403 & 0 & 1 \\
DPOT & 153 & 41.652 & 92.868 & -77.33 & 684.86 \\
BSIZ & 153 & 13.739 & 3.174 & 5 & 21 \\
BGDR & 153 & 14.646 & 10.736 & 0 & 60 \\
TDTA & 153 & 86.943 & 19.254 & 8.63 & 254.75 \\
EITR & 153 & -14.107 & 124.78 & -1504.97 & 192.07 \\
INTC & 153 & 3.328 & 1.644 & -1.81 & 10.52 \\
LAGE & 153 & 22.693 & 15.512 & 2 & 50 \\
SIZE & 153 & 8.958 & .463 & 8.03 & 10.77 \\
CAPE & 153 & 9.765 & 26.520 & -2.5 & 98.45 \\
\hline
\end{tabular}

Table 2 reports the descriptive statistics, indicating the number of observations, mean, minimum and maximum mean. The maximum number of observations is 153. The maximum return on total assets is 9.54 per cent, while the minimum is -20.23 per cent. Audit quality is proxied by dichotomous integer 0 for non-big 4 auditor and 1 for big 4 auditor. On the average, dividend payout ratio is 41.65 per cent. The maximum board size is 21 , while the minimum is 5. The bank with the highest female directors has 60 per cent as women. Results indicate that some banks have zero female directors.

Also, on the average the banks have 86.94 per cent debt in their capital structure. This is not surprising since banks deal in money and frequently borrow from interbank market and or from the Central Bank of Nigeria. The effective corporate income tax rate paid by the banks over the period of study is 14.11 per cent, which is far less than what the fiscal policy suggests. Results in Table 2 further suggest that the banks invested about 3.33 per cent of their assets in intellectual capital. The average listing age is 23 years, while the maximum listing age is 50. Minimum bank size in logarithm is 8.03 , while the maximum is 10.77 . Capital expenditure ratio averages 9.765 per cent for the banks over the period covered by the study.

Table 3

Results of Chen-Shapiro QH* test for normal data

\begin{tabular}{lllll}
\hline Variable & Obs & QH & QH* & P-value \\
\hline OPES & 153 & 0.95468 & 0.56053 & $<0.0001$ \\
ASST & 153 & 0.73650 & 3.25938 & $<0.0001$ \\
ROTA & 153 & 0.84905 & 1.86720 & $<0.0001$ \\
AUDQ & 153 & 0.96722 & 0.40541 & $<0.0001$ \\
DPOT & 153 & 0.66815 & 4.10476 & $<0.0001$ \\
BSIZ & 153 & 1.00675 & -0.08346 & $>0.2$ \\
BGDR & 153 & 0.97062 & 0.36336 & $<0.0001$ \\
TDTA & 153 & 0.67212 & 4.05559 & $<0.0001$ \\
EITR & 153 & 0.43583 & 6.97838 & $<0.0001$ \\
INTC & 153 & 0.97749 & 0.27849 & $<0.0001$ \\
LAGE & 153 & 0.94569 & 0.67173 & $<0.0001$ \\
SIZE & 153 & 0.99562 & 0.05423 & 0.00620 \\
CAPE & 153 & 0.64337 & 4.41132 & $<0.0001$ \\
\hline
\end{tabular}

Results in Table 3 indicate that only board size (BSIZ) is normally distributed because its p-value is greater than .05, which is the criterion adopted in this paper. The remaining variables failed normality test. 
Table 4

Cameron \& Trivedi's decomposition of IM-test

\begin{tabular}{llll}
\hline Source & chi $^{2}$ & df & p-value \\
\hline Heteroskedasticity & 114.87 & 89 & 0.035 \\
Skewness & 6.54 & 12 & 0.887 \\
Kurtosis & 4.43 & 1 & 0.035 \\
Total & 125.85 & 102 & 0.055 \\
\hline
\end{tabular}

Table 4 shows that the overall p-value is not significant at .05 . Thus, implies that there is no heteroskedasticity problem in the model.

Table 5

Results of multicollinearity test

\begin{tabular}{lll}
\hline Variable & VIF & 1/VIF \\
\hline SIZE & 1.99 & 0.503667 \\
TDTA & 1.57 & 0.636187 \\
INTC & 1.43 & 0.698248 \\
ROTA & 1.35 & 0.739625 \\
AUDQ & 1.27 & 0.789604 \\
LAGE & 1.26 & 0.792145 \\
BSIZ & 1.21 & 0.824657 \\
CAPE & 1.17 & 0.851133 \\
BGDR & 1.15 & 0.865807 \\
DPOT & 1.11 & 0.901231 \\
EITR & 1.05 & 0.953114 \\
Mean VIF & 1.38 & \\
\hline
\end{tabular}

Table 5 contains the results of multicollinearity test, which shows that there is no multicollinearity among the independent variables since the VIFs are less than 3.3.

Table 6

Results of correlation analysis

\begin{tabular}{llllllllllll}
\hline Var & ROTA & AUDQ & DPOT & BSIZ & BGDR & TDTA & EITR & INTC & LAGE & SIZE & CAPE \\
\hline ROTA & 1.000 & & & & & & & & & & \\
AUDQ & .2764 & 1.000 & & & & & & & & & \\
& $.0005^{*}$ & & & & & & & & & & \\
DPOT & .0120 & -.1494 & 1.000 & & & & & & & & \\
& .8828 & .0654 & & & & & & & & & \\
BSIZ & .0913 & -.0930 & $.1662^{*}$ & 1.000 & & & & & & & \\
& .2615 & .2526 & .0401 & & & & & & & & \\
BGDR & .1194 & .0641 & .0971 & .1185 & 1.000 & & & & & & \\
& .1416 & .4308 & .2322 & .1447 & & & & & & & \\
TDTA & $-.334^{*}$ & $-.227^{*}$ & -.0949 & $-.217^{*}$ & .0175 & 1.000 & & & & & \\
& .0000 & .0048 & .2433 & .0069 & .8296 & & & & & & \\
EITR & .0547 & .1349 & -.0660 & -.1238 & -.051 & .0399 & 1.000 & & & & \\
& .5021 & .0964 & .4178 & .1275 & .5325 & .6244 & & & & & \\
INTC & $.3184^{*}$ & $.1996^{*}$ & .0821 & .0870 & $.204^{*}$ & -.0579 & .0128 & 1.000 & & & \\
& .0001 & .0134 & .3131 & .2850 & .0116 & .4774 & .8756 & & & & \\
LAGE & -.1318 & .1151 & -.0114 & .1423 & .1217 & .1017 & .0741 & -.0820 & 1.000 & & \\
& .1044 & .1564 & .8889 & .0794 & .1339 & .2109 & .3625 & .3134 & & & \\
SIZE & .1682 & .1051 & .1275 & $.2770 *$ & $.306^{*}$ & $-.224^{*}$ & -.037 & $.322^{*}$ & $.273^{*}$ & 1.000 & \\
& .0377 & .1960 & .1162 & .0005 & .0001 & .0054 & .6532 & .0000 & .0006 & & \\
CAPE & -.0333 & .0486 & -.0814 & -.0275 & .1487 & .0937 & -.002 & $.250^{*}$ & .0811 & $.243^{*}$ & 1.000 \\
& .6825 & .5505 & .3171 & .7357 & .0667 & 2494 & .9826 & .0018 & .3189 & .0025 & \\
\hline
\end{tabular}


Table 6 serves two purposes, testing bivariate collinearity and predicting association between the explanatory variables. For example, none of the coefficients is up to $80 \%$, which is the required threshold for detecting the presence of multicollinearity. This result also confirms the results in Table 5, which show that there is no collinearity. It also highlights associations that are significant; for example, the nexus between profitability and audit quality, intellectual capital and profitability, intellectual capital and audit quality, board size and dividend payout, firm size and board size, intellectual capital and board gender diversity, firm size and board gender diversity, size and intellectual capital, capital expenditure and intellectual capital, size and age, capital expenditure ratio and size are significantly positive. However, the association between leverage and profitability, leverage and audit quality, leverage and board size, size and leverage are significantly negative.

Table 7

Panel effects test

\begin{tabular}{lll}
\hline Model & OPES & ASST \\
\hline chibar $^{2}(01)$ & 0.00 & 0.00 \\
Prob $>$ chibar $^{2}$ & 1.0000 & 1.0000 \\
\hline
\end{tabular}

Results in Table 7 indicate that there are no panel effects in the two models. Therefore, we employed OLS regression technique for both models.

Also, prior to the estimation of the two models (Equations 1 \& 2); we assess Granger non-causality between bankspecific attributes and operational efficiency.

Table 8

Results of Granger non-causality test

\begin{tabular}{llll}
\hline Tests & xtgcause e ASST & xtgcause ASST e \\
\hline W-bar & 4.5059 & 3.3794 & \\
Z-bar & $8.5876 \quad(\mathrm{p}$-value $=0.0000)$ & $5.8284 \quad(\mathrm{p}$-value $=0.0000)$ \\
Z-bar tilde & $4.8501 \quad(\mathrm{p}$-value $=0.0000)$ & $3.1535 \quad(\mathrm{p}$-value $=0.0016)$ \\
\hline
\end{tabular}

Results in Table 8 indicate that there are bilateral associations between bank-specific attributes and operational efficiency. This is because the p-values for both relationships are significant. Results in Table 9 show that the two models are fit because their Prob > F p-values are significant. However, Model ASST is more superior to Model OPES because it has better $\mathrm{F}(12,140)$ of 17.04 than 9.64 statistics, $\mathrm{R}^{2}$ of 59.35 per cent than 45.25 per cent and adjusted $\mathrm{R}^{2}$ of 55.87 per cent than 40.56 per cent. Hence, Model ASST is used to test the hypotheses.

As indicated in Table 9, four independent variables: profitability (ROTA), leverage (TDTA), intellectual capital (INTC) and capital expenditure ratio (CAPE) show significant effect on bank operational efficiency because their pvalues are significant at .05 level. However, the remaining 7 variables failed to indicate significance at any level. One of the implications of these results is that managers should concentrate greater attention to the quality of asset turnover than operating expenses to sales.

Meanwhile, it is worth noting that asset turnover is made up of net sales and total assets. This suggests that managers should adopt strategies to boost sales and improve on the quality of firm's assets. Sales could be boosted by way of integrated marketing strategies, customer satisfaction measures and development of new customer-friendly products. Similarly, asset quality could be improved by way of reinvesting profit to expand system networks, acquire new systems, open new branches, renew or rehabilitate existing physical infrastructures. 
Table 9

OLS Regression Results

\begin{tabular}{lllllll}
\hline Model & OPES & & \multicolumn{3}{l}{ ASST } \\
Variable & Coef. & $\mathrm{t}$ & $\mathrm{P}>\mathrm{t}$ & Coef. & $\mathrm{t}$ & $\mathrm{P}>\mathrm{t}$ \\
\hline ROTA & -1.528 & -2.66 & 0.009 & -.002 & -2.33 & 0.021 \\
AUDQ & -.021 & -0.01 & 0.996 & -.006 & -0.92 & 0.359 \\
DPOT & -.012 & -0.73 & 0.464 & .00001 & 0.04 & 0.965 \\
BSIZ & -.131 & -0.26 & 0.796 & .0001 & 0.14 & 0.886 \\
BGDR & .397 & 2.73 & 0.007 & -.0001 & -0.49 & 0.623 \\
TDTA & -.165 & -1.74 & 0.084 & .0010 & 6.60 & 0.000 \\
EITR & .0076 & 0.63 & 0.527 & .00001 & 0.56 & 0.578 \\
INTC & -7.029 & -6.64 & 0.000 & .0086 & 4.92 & 0.000 \\
LAGE & -.104 & -0.99 & 0.324 & -.00011 & -0.64 & 0.526 \\
SIZE & 1.342 & 0.30 & 0.762 & -.0038 & -0.52 & 0.601 \\
CAPE & -.126 & -2.12 & 0.036 & .00023 & 2.31 & 0.022 \\
cons & 83.819 & 2.05 & 0.042 & -.0135 & -0.20 & 0.842 \\
F $(12,140)$ & 9.64 & & & 17.04 & & \\
Prob $>$ F & 0.0000 & & & 0.0000 & & \\
R-squared & 0.4525 & & & 0.5935 & & \\
Adj R-squared & 0.4056 & & & 0.5587 & & \\
\hline
\end{tabular}

Results in Table 9 suggest that we reject the null hypotheses 5, 7, 8 and 11 since their t-values and p-values are significant. This conclusion is in line with the findings of Setiawan and Kodralillah (2017), Lotto (2019), Bitar et al. (2018), Onyekwelu et al. (2017), Ewereoke (2018) and Gadzo and Asiamah (2018). However, we accept the null hypotheses 1,2, 3, 4, 6, 9 and 10 because their t-values and p-values are not statistically significant, which are in agreement with the findings of Ugwu et al. (2020), Zulkufy et al. (2015), Agoraki et al. (2010), Ahmad and Muqaddas (2016), Gawehn (2019) and Lundvall and Battese (2000).

\section{Conclusion and Recommendations}

In this paper, we contribute to empirical literature by interrogating the influence of bank attributes on efficiency using more refined econometric models. This was achieved by considering 12 quoted deposit money banks over a period of 13 years (2007-2019). Factor analysis indicates that 11 of the 15 bank-specific attributes have eigenvalues greater than 1 and therefore entered into the econometric models. The descriptive statistics indicate that xx. The results of normality test show that only board size is normally distributed, the remaining variables failed normality test. Also, the results of homoscedasticity test indicate that the two models do not have heteroskedasticity problem since there pvalues are not significant. The results of multicollinearity test indicate that all the explanatory variables are free of multicollinearity. Also, the correlation matrix indicates that some of the explanatory variables are significantly associated, while others are not. The panel effects test results suggest that there is no panel effect in the two models and therefore requires adoption of OLS regression. The Granger non-causality test results indicate the presence of bidirectional cause and effect relationship. The regression models indicate that asset turnover is superior to OPES. The results further indicate that only profitability, leverage, intellectual capital and capital expenditure ratio determine bank operational efficiency in Nigeria. In view of these conclusions, we suggest that bank managers should pay greater attention to profit, total assets, debt profile, intellectual capital (human, structural, relational and capital employed), cash from operations and capital expenditures.

\section{References}

Abu, S. O., Yahaya, O. A., \& Abah, C. (2018). Audit committee effectiveness and audit quality of listed insurance companies in Nigeria. International Journal of Research in Finance and Management, 1(2), 37-46.

Abu, S. O., Okpanachi, J., \& Yahaya, O. A. (2019). Family and foreign ownership and audit quality of listed manufacturing firms in Nigeria. Global J. of Management and Business Research (Accounting and Auditing), 19(1-D), 69-79. doi: https://journalofbusiness.org/index.php/GJMBR/issue/view/402.

Adeabah, D., Gyeke-Dako, A., \& Andoh, C. (2019). Board gender diversity, corporate 
governance and bank efficiency in Ghana: A two stage data envelope analysis approach. Corp. Governance, 19(2), 299-320. https://doi.org/10.1108/CG-08-2017-0171.

Agoraki, M-E. K., Delis, M. D., \& Staikoroueas, P. (2010). The effect of board size and composition on bank efficiency. International Journal of Banking Accounting and Finance, 2(4), 01-29. DOI: 10.1504/IJBAAF.2010.037155.

Ahmad, I., \& Muqaddas, M. F. (2016). Determinants of dividend payout policy: An empirical study of banking sector of Pakistan. Applied Studies in Agribusiness and Commerce, 10(4-5), 101-106. DOI: 10.19041/APSTRACT/2016/4-5/13.

Bhatti, G. A., \& Hussain, H. (2010). Evidence on structure conduct performance hypothesis in Pakistani commercial banks. Int. Journal of Business and Management, 5(9), 174-187.

Bitar, M., Pukthuanthong, K., \& Walker, T. (2018). The effect of capital ratios on the risk, efficiency and profitability of banks: Evidence from OECD countries. Journal of International Financial Markets Institutions and Money (Forthcoming). DOI: 10.1016/j.intfin.2017.12.002.

Boubaker, S., Houcine, S., Ftiti, Z., \& Masri, H. (2018). Does audit quality affect firms' investment efficiency? Journal of the Operational Research Society,69(10), 1688-1699. DOI: 10.1080/01605682.2018.1489357.

Buallay, A., Hamdan, A. M., Reyad, S., Badawi, S., Madbouly, A. (2020). The efficiency of GCC banks: the role of intellectual capital. European Business Review, 32(3), 383404. https://doi.org/10.1108/EBR-04-2019-0053.

Chan, S-G., \& Karim, M. Z. A. (2010). Bank efficiency, profitability and equity capital: Evidence from developing countries. American J. Fin. \& Accounting, 2(2), 181-195.

Ekwe, M. C. (2013). The relationship between intellectual capitals and growth in revenue of deposit money banks in Nigeria. Research J. of Finance and Accounting, 4(12), 55-64.

Enekwe, C. I., Nweze, A. U., \& Agu, C. I. (2015). The effect of dividend payout on performance evaluation: Evidence of quoted cement companies in Nigeria. European J. of Acc., Auditing and Finance Research, 3(11), 40-59.

Eriki, P. O., \& Osifo, O. (2015). Determinants of performance efficiency in Nigerian banking industry: A DEA approach. Int. J. of Econ., Commerce and Management, 3(2), 01-13.

Ewereoke, V. (2018). Effect of intellectual capital on performance of firms listed on Nigerian Stock Exchange. Research Journal of Finance and Accounting, 9(8), 138-150.

Gadzo, S. G., \& Asiamah, S. K. (2018). Assessment of the relationship between leverage and performance: An empirical study of unlisted banks in Ghana. Journal of Economics and International Finance, 10(10), 123-133. DOI: 10.5897/JEIF2018.0920.

Gaganis, C., Pasiouras, F., \& Tsaklanganos, A. (2013). Taxation and bank efficiency: Crosscountry evidence. International Journal of the Economics of Business, 20(2), 229-244. https://doi.org/10.1080/13571516.2013.782984.

Gawehn, V. (2019). Banks and corporate income taxation: A review. Quantitative Research in Taxation - Discussion Papers, arqus Discussion Paper No. 247.

Homma, T., Tsutsui, Y., \& Uchida, H. (2012). Firm growth and efficiency in the banking industry: A new test of the efficient structure hypothesis. Working Paper No. 272, University of Toyama, Japan.

Jeroh, E., Ekwueme, C. M., Edesiri, O. G. (2015). Corporate governance, financial performance and audit quality of listed firms in Nigeria. J. of Acad. Res. in Economics, 7(2), 220-231.

Kaiser, H. F. (1960). The application of electronic computers to factor analysis. Educational and Psychological Measurement, 20, 141-151.

Kaiser, H. F. (1970). A second-generation Little Jiffy. Psychometrika, 35, 401-415.

Kamarudin, F., Sufian, F., Nassir, A. M., Anwar, N. A. M., \& Hussain, H. I. (2019). Bank efficiency in Malaysia a DEA Approach. J. of Central Banking Theory and Practice, 1, 133-162. DOI: 10.2478/jcbtp-2019-0007.

Lotto, J. (2019). Evaluation of factors influencing bank operating efficiency in Tanzanian banking sector. Cogent Economics and Finance, 7(1), 01-14. https://doi.org/10.1080/23322039.2019.1664192.

Odunga, R. M., Nyangweso, P. M., Nkobe, D. K. (2013). Liquidity, capital adequacy and operating efficiency of commercial banks in Kenya. Res. J. of Fin. \& Acc., 4(8), 76-80.

Lundvall, K., \& Battese, G. E. (2000). Firm size, age and efficiency: Evidence from Kenyan manufacturing firms. The Journal of Development Studies, 36(3), 146-163. Doi: ABI/INFORMGlobal. 
Onwe, E. D., Mustapha, L. O., \& Yahaya, O. A. (2020). Financial structure and financial performance of listed firms in Nigeria. Res. J. of Fin. \& Accounting, 11(14), 120-136

Onyekwelu, U. L., Okoh, J. I., \& Iyidiobi, F. C. (2017). Effect of intellectual capital on financial performance of banks in Nigeria. European J. of Acc., Aud. \& Fin. Research, 5(2), 28-57.

Page Jr., J. M. (1984). Firm size and technical efficiency: Applications of production frontiers to Indian survey data. Journal of Development Economics, 16(1-2), 129-152.

Salawu, M. O., Okpanachi, J., Yahaya, O. A., \& Dikki, A. C. (2017a). Effect of audit committee independence on audit quality of Listed Consumer-Goods Companies in Nigeria. Int. J. of Education and Res., 5(11), 47-62

Salawu, M. O., Okpanachi, J., Yahaya, O. A., \& Dikki, A. C. (2017b). Effects of audit committee expertise and meetings on audit quality of Listed Consumer-Goods Companies in Nigeria. European J. of Acc., Auditing and Fin. Research, 5(10), 61-79.

Setiawan, C., \& Kodralillah, O. I. (2017). Examining banks profitability and banks efficiency of Islamic commercial banks in Indonesia. Proceedings of 12th Asia-Pacific Business Research Conference 27 28 February, 2017, Concorde Hotel, Kuala Lumpur, Malaysia.

Shumway, T. (2001). Forecasting bankruptcy more accurately: A simple hazard model. J. of Business, 74, $101-124$.

Sulub, S. A. (2014). Do the bank size, age and leverage are important factors to determine its profitability? Electronic copy is available at http://ssrn.com/abstract $=2417923$.

Tanna, S., Pasiouras, F., \& Nnadi, M. (2011). The effect of board size and composition on the efficiency of UK banks. International Journal of the Economics of Business, 18(2), 441-462. DOI: 10.1080/13571516.2011.618617.

Ugwu, C. C., Aikpitanyi, L. N., \& Idemudia, S. (2020). The effect of audit quality on efficiency of deposit money banks: Evidence from Nigeria. J. of Econ. and Business, 3(1), 270-281. DOI: 10.31014/aior.1992.03.01.196.

Werner, K., \& Moormann, J. (2009). Efficiency and profitability of European banks: How important is operational efficiency? Frankfurt School Working Paper Series III, Frankfurt School of Fin. \& Mgt.

Yahaya, O. A. (2017). Firm performance and dividend policy: A panel data analysis of listed consumer-goods companies in Nigeria. Nig. J. of Mgt. Tech. \& Dev., 8(1), 306-322.

Yahaya, O. A. (2018). Environmental reporting practices and financial performance of listed environmentallysensitive firms in Nigeria. Savanna: A Journal of the Environmental and Social Sciences, 24(2), 403-412. A Publication of the Department of Geography and Environmental Mgt., Ahmadu Bello University, Zaria.

Yahaya, O. A. (2019). Intellectual capital management and financial competitiveness of listed oil and gas firms in Nigeria. ESUT Journal of Management Sciences, 17(2), 77-89.

Yahaya, O. A., Tanko, M., \& Muhammad, L. M. (2017). Effects of corporate characteristics on earnings quality of listed DMBs in Nigeria. KASU J. of Mgt. Sciences, 8(1), 47-64.

Yahaya, O. A., Yusuf, M. J., Onyabe, J. M., \& Awen, B. I. (2017). Bank liquidity and risk exposure in Nigeria. Dutse Journal of Economics and Development Studies, 2(1), 136-154.

Yahaya, O. A., Onyabe, J. M., Yusuf, M. J., \& Bilyaminu, T. (2019). Financial mix and financial performance of listed consumer goods firm in Nigeria. J. of Acc. \& Mgt., 2(1), 226-237.

Yahaya, O. A., \& Onyabe, J, M. (2020). Firm life cycle and financial performance: Evidence from Nigeria. Journal of Accounting and Finance in Emerging Economies, 6(3), 723-732. doi: https://doi.org/10.26710/jafee.v6i3.1332.

Yahaya, O. A., \& Bilyaminu, T. (2020). Internal corporate governance and intellectual capital of listed oil and gas firms in Nigeria. Euro. J. of Acc., Aud. \& Fin. Research, 8(9), 98-109.

Zulkufly, R., Chan, S-G., Mohammed, Z. ., \& Noor, S. S. (2015). Gender diversity, board monitoring and bank efficiency in ASEAN-5. South East Asia J. of Contemporary Bus., Econ. \& Law, 7(1), 9-21. 